\title{
Sports-related dental injuries in children: Knowledge, past experiences and emergency preparedness in a group of sports coaches in two cities of India
}

\author{
Rucha S. Bhise Patil ${ }^{1, *}$, Uma B. Dixit ${ }^{2}$ \\ ${ }^{1}$ Lecturer, ${ }^{2}$ Professor \& HOD, D. Y. Patil University School of Dentistry, Navi Mumbai, Maharashtra, India \\ *Corresponding Author: \\ Email: rucha.shivajirao@gmail.com
}

\begin{abstract}
Objective: To evaluate sports teachers' knowledge, their past experiences of dental injuries and Oro-facial trauma and also to evaluate their emergency preparedness in case of dental injuries while playing.

Material and Method: This questionnaire-based cross-sectional study included 148 sports coaches selected randomly from the cities of Mumbai and Surat in India. They were asked to fill a questionnaire to obtain information regarding socio-demographics, knowledge of dental trauma, past experiences and dental emergency preparedness. Collected data were subjected to descriptive and inferential statistics.

Results: Fifty (33.8\%) sports coaches showed adequate knowledge regarding management of a fractured tooth. Forty (27\%) sports coaches were aware of reimplantation of an avulsed tooth; but none of them were able to exhibit adequate knowledge on its management. Although 39\% of the participants had experienced dental trauma, very few of them exhibited dental emergency preparedness $(7.4 \%)$. Professional training in sports coaching was positively associated with significantly better special knowledge $(\mathrm{p}=0.042)$. Coaching experience was not found to be associated with the knowledge or preparedness.

Conclusions: There is a serious need of inclusion of modules on management of dental trauma as a part of professional sports training programs in India.
\end{abstract}

Keywords: Sports Coaches, Play-ground, Dental Trauma, Trauma Knowledge, Avulsion.

\section{Introduction}

Participation in sports can have physical and social benefits for children. Increased participation in sports by children has contributed to an increase in sports related injuries. ${ }^{1}$ According to the American Academy of Pediatric Dentistry's Policy on Prevention of sportsrelated oro-facial injuries, sports accidents account for 10 to 39 percent of all dental injuries in children. ${ }^{2}$

Occurrence of oro-facial injuries in children due to active sports has been widely reported world wide ${ }^{3}$ and in India. ${ }^{4-10}$ Observational studies have suggested that traumatic dental injuries have negative impact on oral health related quality of life in children. ${ }^{11-13}$

Sports coaches who are involved in teaching active sports to children in school or outside of school usually come across such injuries. ${ }^{14-16}$ Delay in immediate treatment or improper treatment due to lack of knowledge may lead to unsuccessful outcome of the treated injured teeth. In the absence of parents, sports coaches bear responsibility to manage the injuries occurring on the playgrounds.

In India, University-based diploma, degree and post-graduate programs are available to be trained as sports coaches. Individuals without any professional training do engage in sports training of children. Most of the degree or diploma programs do not include modules on management of dental trauma. Literature search revealed very few studies from India that assess the knowledge of sports coaches about management of dental injuries. Therefore, we designed this study to evaluate the knowledge of sports coaches regarding management of dental injuries in children and to assess their past experiences and emergency preparedness related to dental injuries.

\section{Materials and Method}

This cross-sectional survey-based study was approved by the Institutional Ethical Committee. Target population of this study was sports coaches; either selfemployed, or employed in schools or sports clubs; who coached active sports to children of all ages. Sports coaches fulfilling these criteria from the cities of Mumbai and Surat were randomly selected and contacted regarding the scope of the study. A total of 175 coaches agreed to participate in the study. Informed consents were obtained from the included sports coaches and they were asked to fill a questionnaire that was validated on a smaller sample of sports coaches $(\mathrm{N}=25)$ which was not included in the study sample.

The questionnaire for sports coaches was divided into 4 parts. The first part included information regarding socio-demographic data. The second part included questions on general knowledge (4 questions) and special knowledge (5 questions) regarding management of dental injuries. Each question in this section was scored 0 for an inappropriate answer and 1 for the appropriate answer. Mean general knowledge score and mean special knowledge score were calculated from the collected data.

The third part included 4 questions regarding their past experiences of traumatic dental injuries while coaching children. The fourth part evaluated dental trauma preparedness of the sports coaches, which included a total of 3 questions. Bringing a child to a 
dentist upon dental injury, strict approach in using mouth guards while playing and storing dentists' numbers for use in emergency were considered as adequate preparedness. All the appropriate answers were given a score 1 and inappropriate answers were scored as 0 .

Collected data were entered in an Excel spreadsheet (Excel 2013; Microsoft Corporation, Redmont, WA, USA) for analysis. Descriptive statistics were computed to demonstrate the frequency of responses. Association of receiving professional sports training and coaching experience with the knowledge and preparedness was analyzed using a Chi Square test.

\section{Results \\ Socio-demographic data}

One hundred and forty eight sports coaches out of 175 responded to the questionnaire (response rate: $84.6 \%$ ), whose characteristics are presented in the Table 1. Most of the sports coaches were males $(85 \%)$ and located in large cities $(78 \%)$. One hundred and two (69\%) of total 148 sports coaches had completed a degree or diploma in sports training. Age of selected sports coaches ranged from 19 years to 59 years with the mean age of 34.5 (7.66) years.

Out of 148 sports coaches teaching active sports to children below 18 years,75 (50.7\%) were employed in schools or colleges, $48(32.4 \%)$ were self-employed and $25(16.9 \%)$ were employed with sports clubs or academies. Most of the participants had coaching experience of more than 4 years $(77.1 \%)$.

\section{General knowledge of dental trauma management}

Although all the participants in our study were involved in coaching active sports to children, only $49.3 \%$ were aware that sports activities coached by them had a potential to cause dental and oro-facial injuries (Table 2). Only $20.3 \%$ sports coaches had knowledge that an avulsed permanent tooth can be reimplanted. Similarly, only $66.8 \%$ coaches displayed adequate knowledge regarding mouth guards being used for prevention of dental injuries and $46 \%$ sports coaches were aware that mouth guards were available at sports store or custom-made by dentists. Average general knowledge score was calculated as 1.75 . Only 1 participant out of all the 148 sports coaches could give all the answers correctly on general knowledge of dental trauma.

\section{Special knowledge of dental trauma management}

Of all the 40 sports coaches who answered that a knocked out tooth could be reimplanted, $65 \%$ responded that they would clean the knocked out tooth (Table 3). For cleaning the tooth, only $57.7 \%$ showed adequate knowledge of cleaning it under tap water without touching root of the tooth. Rest gave inappropriate answers like rubbing the tooth with fingers under tap water $(19.2 \%)$ or scrubbing the tooth with a tooth brush under tap water (7.7\%).Some of them $(15.4 \%)$ stated that they would clean the tooth with antiseptic solution like Savlon or Dettol.

While responding to the question regarding storage of an avulsed tooth until reimplantation, only $47.5 \%$ sports coaches exhibited adequate knowledge, i.e., storing it in milk or saliva. Others chose inappropriate options like tissue paper $(25 \%)$, cold water $(20 \%)$, and hot water $(7.5 \%)$.

In response to the question on the extra-oral time permissible for a tooth prior to reimplantation, only 8 (20\%) participants indicated less than 30 minutes to be appropriate. Adequate knowledge of tooth fragment reattachment in case of a broken tooth was shown by 50 $(33.8 \%)$ sports coaches. Average special knowledge score was calculated as 0.8 . None of the participants could exhibit the complete special knowledge of dental trauma.

\section{Past experiences of dental trauma}

Past experiences of the sports coaches regarding dental injuries in their students are presented in the Table 4. Fifty-eight (39.1\%) sports coaches had witnessed injuries and permanent damage to teeth of their students during coaching or competitions and 52 (35.1\%) had to consult a dentist for such injuries. Forty-seven (31.7\%) coaches came across medical emergencies during coaching that required medical help.

\section{Dental emergency preparedness}

Table 5 summarizes data on emergency preparedness of sports coaches for dental injuries in their students. Out of 148 sports coaches, only $23 \%$ said that they would take a child to a dentist in case of a dental injury. For preventive measures, only $52.7 \%$ of the sports coaches admitted to follow all safety measures like use of mouth guards, helmets strictly. Fifty-nine percent coaches admitted that they saved the near-by dentist's contact number to be used in case of dental injury. Average dental emergency preparedness score of the sample was found to be $1.34(0.88)$.

\section{Association of professional sports training with knowledge}

Out of 148 sports coaches included in the study, 102 were professionally trained with a degree in sports training. Mean scores of general knowledge, special knowledge and emergency preparedness were found to be higher in the sports coaches who were professionally trained as compared to coaches who were not. This difference reached statistical significance in special knowledge score $(p=0.042)$. Our results showed that coaching experience (less than or equal to 4 years as compared to more than 4 years) was not significantly associated with general knowledge, special knowledge or dental emergency preparedness of sports coaches. 
Table 1: Distribution of sample of sports coaches

\begin{tabular}{|c|c|c|}
\hline \multirow{2}{*}{ Characteristics } & \multicolumn{2}{|c|}{ Sports coaches $(\mathrm{N}=148)$} \\
\hline & Number & Percent \\
\hline \multicolumn{3}{|l|}{ Gender } \\
\hline Males & 126 & $85.1 \%$ \\
\hline Females & 22 & $14.9 \%$ \\
\hline \multicolumn{3}{|l|}{ City type } \\
\hline Large city & 116 & $78.4 \%$ \\
\hline Small city/ Town & 32 & $21.6 \%$ \\
\hline \multicolumn{3}{|l|}{ Educational status } \\
\hline Some high school & 26 & $17.6 \%$ \\
\hline Some college & 62 & $41.9 \%$ \\
\hline Post graduate degree & 60 & $40.5 \%$ \\
\hline \multicolumn{3}{|c|}{ Degree/Diploma in sports training } \\
\hline Yes & 102 & $68.9 \%$ \\
\hline No & 46 & $31.1 \%$ \\
\hline \multicolumn{3}{|l|}{ Job profile } \\
\hline Employed in school/college & 75 & $50.7 \%$ \\
\hline Self employed & 48 & $32.4 \%$ \\
\hline $\begin{array}{l}\text { Employed in sports club/ } \\
\text { academy }\end{array}$ & 25 & $16.9 \%$ \\
\hline \multicolumn{3}{|l|}{ Coaching experience } \\
\hline$<1$ year & 11 & $7.4 \%$ \\
\hline $1-4$ years & 23 & $15.5 \%$ \\
\hline$>4$ years & 114 & $77.1 \%$ \\
\hline Mean Age \pm SD & \multicolumn{2}{|c|}{34.5 years $(7.66)$} \\
\hline
\end{tabular}

Table 2: General knowledge of sports coaches regarding management of dental emergencies Questions Sports coaches $(\mathrm{N}=148)$ Number $\quad$ Percent

1. Do sports activities supervised by you cause injuries to head, oro-facial structures or teeth (dental trauma)? \begin{tabular}{|l|c|c} 
Yes & 73 & $49.3 \%$ \\
\hline
\end{tabular}

2. Can a tooth that has been knocked out of mouth while playing be put back in the gum again?

\begin{tabular}{|c|c|c|}
\hline I am not aware & 80 & $54.0 \%$ \\
\hline $\begin{array}{l}\text { No, it cannot be placed } \\
\text { back in the gum }\end{array}$ & 28 & $18.9 \%$ \\
\hline $\begin{array}{l}\text { Yes, if it is a permanent } \\
\text { tooth }\end{array}$ & 30 & $20.3 \%$ \\
\hline $\begin{array}{l}\text { Yes, for both milk tooth } \\
\text { and permanent tooth }\end{array}$ & 10 & $6.7 \%$ \\
\hline \multicolumn{3}{|c|}{ 3. Do mouth guards aid in prevention of dental injuries? } \\
\hline Yes & 99 & $66.8 \%$ \\
\hline \multicolumn{3}{|c|}{ 4. Availability of mouth guards } \\
\hline Medical store & 75 & $50.6 \%$ \\
\hline Sports store & 56 & $37.83 \%$ \\
\hline Custom made by dentist & 12 & $8.1 \%$ \\
\hline General store & 5 & $3.37 \%$ \\
\hline $\begin{array}{l}\text { General knowledge score } \\
(\text { Mean } \pm S D)\end{array}$ & \multicolumn{2}{|c|}{$1.75(0.91)$} \\
\hline
\end{tabular}


Table 3: Special knowledge of sports coaches regarding management of dental emergencies

\begin{tabular}{|c|c|c|}
\hline \multirow{2}{*}{ Questions } & \multicolumn{2}{|c|}{ Sports coaches $(\mathrm{N}=30)$} \\
\hline & Number & Percent \\
\hline \multicolumn{3}{|l|}{ 1. Cleaning of avulsed tooth } \\
\hline \multicolumn{3}{|l|}{ 1.1 Will you clean the knocked out tooth? $(\mathrm{N}=40)$} \\
\hline Yes & 26 & $65 \%$ \\
\hline No & 14 & $35 \%$ \\
\hline Adequate knowledge & 26 & $65 \%$ \\
\hline \multicolumn{3}{|l|}{1.2 Cleaning method? $(\mathrm{N}=26)$} \\
\hline By holding it under tap water & 15 & $57.7 \%$ \\
\hline $\begin{array}{l}\text { By rubbing the tooth with fingers under tap } \\
\text { water }\end{array}$ & 5 & $19.2 \%$ \\
\hline By using a tooth brush and tap water & 2 & $7.7 \%$ \\
\hline By using antiseptic solution like Savlon, Dettol & 4 & $15.4 \%$ \\
\hline Adequate knowledge & 15 & $57.7 \%$ \\
\hline \multicolumn{3}{|l|}{ 2. Storage of an avulsed tooth $(\mathrm{N}=40)$} \\
\hline Will keep it dry in a tissue paper or cotton & 10 & $25 \%$ \\
\hline Will keep it in cold water & 8 & $20 \%$ \\
\hline Will keep it in warm/hot water & 3 & $7.5 \%$ \\
\hline Will keep it in milk & 15 & $37.5 \%$ \\
\hline Will hold it in mouth & 4 & $10 \%$ \\
\hline Adequate knowledge & 19 & $47.5 \%$ \\
\hline \multicolumn{3}{|l|}{ 3. Time of replantation $(\mathrm{N}=40)$} \\
\hline Adequate knowledge & 8 & $20 \%$ \\
\hline \multicolumn{3}{|l|}{ 4. Tooth fragment reattachment $(\mathrm{N}=148)$} \\
\hline Adequate knowledge & 50 & $33.7 \%$ \\
\hline
\end{tabular}

Table 4. Past experiences of sports coaches regarding dental injuries in their students \begin{tabular}{|l|c|c|}
\multirow{2}{*}{ Questions } & \multicolumn{2}{|c|}{ Sports coaches (N=148) } \\
\cline { 2 - 3 } & Number & Percent \\
\hline
\end{tabular}

1. Has any athlete under you suffered from a permanent damage to his/her teeth due to the injury during coaching or competitions?

\begin{tabular}{|l|c|c|}
\hline Yes & 58 & $39.1 \%$ \\
\hline No & 90 & $60.9 \%$ \\
\hline
\end{tabular}

2. Did you have to consult a dentist or a doctor for these injuries?

\begin{tabular}{|l|c|c|}
\hline Yes & 52 & $35.1 \%$ \\
\hline No & 96 & $64.9 \%$ \\
\hline
\end{tabular}

3. How many times in the last year have students/athletes under your care sustained oro-facial or dental injuries?

\begin{tabular}{|l|c|c|}
\hline None & 90 & $60.9 \%$ \\
\hline $1-3$ times & 49 & $33.1 \%$ \\
\hline 4-6 times & 9 & $6 \%$ \\
\hline More than 6 & 0 & $0 \%$ \\
\hline 4 Din
\end{tabular}

4. Did you come across any medical emergency during coaching / competition that required medical help?

\begin{tabular}{|l|c|c|}
\hline Yes & 47 & $31.7 \%$ \\
\hline No & 101 & $68.3 \%$ \\
\hline
\end{tabular}

Table 5: Dental emergency preparedness of sports coaches

\begin{tabular}{|l|c|c|}
\hline \multicolumn{2}{|c|}{ Questions } & \multicolumn{2}{c|}{ Sports coaches (N=148) } \\
\cline { 2 - 3 } & Number & Percent \\
\hline 1. Action on dental emergency & 34 & $22.9 \%$ \\
\hline Adequate & 114 & $77.1 \%$ \\
\hline Inadequate & \multicolumn{2}{|c}{} \\
\hline 2. Approach in following safety measures
\end{tabular}




\begin{tabular}{|l|c|c|}
\hline Adequate & 78 & $52.7 \%$ \\
\hline Inadequate & 70 & $47.3 \%$ \\
\hline 3. Stored dentists' contact numbers in case of emergency? \\
\hline Adequate & 87 & $58.7 \%$ \\
\hline Inadequate & 61 & $41.3 \%$ \\
\hline Preparedness score (Mean \pm SD) & $\mathbf{1 . 3 4 ( 0 . 8 8 )}$ \\
\hline
\end{tabular}

\section{Discussion}

Children participating in active sports are at higher risk of oro-facial injuries ${ }^{13,17}$ due to falls, collisions, hand or elbow blows, and direct impact with sports related equipment. Some of the estimates show that individuals participating in active sports have $10 \%$ chance to suffer from dental injuries. ${ }^{18}$ Most of the dental injuries involve maxillary anterior teeth ${ }^{19}$ causing crown fractures, dislocations and avulsion. Such injuries to permanent teeth require long-term treatment and success is hampered due to inappropriate immediate management.

Forty percent of the sports coaches from our study noted of having experienced traumatic dental injuries in children coached by them in the past. However, very few acknowledged that sports coached by them could lead to dental injuries.

We found that knowledge of the management of avulsed primary and permanent teeth was very low in our sample of sports coaches. Similar findings have been reported by other researchers. ${ }^{14,15}$ The important factor that influences the success of the treatment of an avulsed tooth is extra-oral dry time of an avulsed tooth. Delay in providing emergency dental treatment may lead to unsuccessful treatment outcome of an avulsed tooth. In the present study, very few sports coaches (20.3\%) recognized the urgency of reimplantation of an avulsed tooth. Our finding is in accordance with other studies conducted on sports coaches. ${ }^{13,20,21}$ It was further observed that the sports coaches who were knowledgeable about possibility of reimplantaion of an avulsed permanent tooth did not display adequate knowledge of cleaning and storage of an avulsed tooth prior to reimplantation. Although, $75 \%$ of the sports coaches were aware that the tooth should be kept in a liquid, the type of liquid used was not known. Other transport media like HBSS and Viaspan were not included in the choices because they are not readily available at the site of accident. A choice of "Others (please specify)" was provided, and sports coaches could fill these answers if they knew any of these mediums, but none of the respondent mentioned any of these solutions.

Dental trauma during participation in active sports can be prevented by using preventive gear like mouth guards, helmets and face masks. ${ }^{22}$ The Academy of Sports Dentistry lists 40 contact sports and recommends use of mouth guards in them. Our results revealed inadequate knowledge of preventive measures in the sports coaches. It could be because there is no law that makes it mandatory to use protective devices such as mouth guards during practice of an active sport. Similar findings have been reported earlier. ${ }^{23,24}$ Our finding is alarming in the light that many sports coaches had experienced dental injuries in their students while playing. This suggests the need for sports coaches to be well educated in dental emergency management.

To the best of our knowledge none of the studies in the literature has evaluated the preparedness of sports coaches in case of dental emergencies. Our sample of sports coaches showed inadequate preparedness towards dental injuries despite knowing and experiencing that sports activities taught by them could lead to dental injuries.

Various studies have shown that various methods in improving knowledge and practices of dental trauma management of individuals have contributed to reduction or prevention of traumatic dental injuries. ${ }^{25-30}$ There are several ways to increase public and sports coaches' awareness which include poster presentation at playgrounds, lectures and discussions as well as use of newer technology like smart phones is also recommended.

Extrapolation of the results of this study to general population of sports coaches should be done with caution as the sample selected represents regional population of sports coaches.

\section{Conclusion}

Sports coaches included in our study exhibited inadequate knowledge and emergency preparedness regarding management of dental injuries. Our findings emphasize a need for dental emergency management to be included in training programs for sports coaches and physical education teachers.

\section{Finincial Support: Nil}

Conflict of Interest: None

\section{References}

1. Dennis $\mathrm{C}$, Caine $\mathrm{C}$, Maffulli N. Incidence and distribution of pediatric sport-related injuries. Clin J Sport Med 2006;16:500-13.

2. American Academy of Pediatric Dentistry: Policy on Prevention of Sports-related Orofacial Injuries. Pediatr Dent 2013;39(6):85-9.

3. Azami-Aghdash S, Ebadifard AF, Pournaghi AF, Rezapour A, Moradi-Joo M, Moosavi A, Ghertasi OS. Prevalence, etiology and types of dental trauma in children and adolescents: systematic review and metaanalysis. Med J Islam Repub Iran 2015;29(4):234.

4. Bhayya DP, Shyagali TR. Traumatic injuries in the primary teeth of 4 to 6 year-old school children in Gulbarga city, India. A prevalence study. Oral Health Dent Manag 2013;12(1):17-23. 
5. Tasneem S, Telgi RL, Sultan S, Tangade P, Telgi CR, Tirth A, Pal SK, Gowhar O, Tandon V. Prevalence of traumatic dental injuries to anterior teeth of 12-year-old school children in Kashmir, Ind Arch Trauma Res 2016;5(1):e245-96.

6. Gupta K, Tandon Sb, Prabhu D. Traumatic injuries to the incisors in children of south kanara district. A prevalence study. J Ind Soc Pedo Prev Dent 2002;20(3):107-13.

7. Patel MC, Sujan SG. The prevalence of traumatic dental injuries to permanent anterior teeth and its relation with predisposing risk factors among 8-13 years school children of Vadodara city: An epidemiological study. $J$ Ind Soc Pedod Prev Dent 2012;30(2):151-7.

8. Sharma S, Anand MK, Kaur A, Kaur R, Jindal S, Aggarwal N. Traumatic dental injuries in preschoolers: A Neglected and rising epidemic in India. Am J Adv Med Sci 2014;2(2):15-23.

9. Govindarajan M, Reddy VN, Ramalingam K, Durai KS, Rao PA, Prabhu A. Prevalence of traumatic dental injuries to the anterior teeth among three to thirteen-yearold school children of Tamilnadu. Contemp Clin Dent 2012;3:164-7

10. Prabhu A, Rao AP, Govindarajan M, Reddy V, Krishnakumar R, Kaliyamoorthy S. Attributes of dental trauma in a school population with active sports involvement. Asian J Sports Med 2013;4(3):190-4.

11. Borges TS, Vargas-Ferreira F, Kramer PF, Feldens C. Impact of traumatic dental injuries on oral health-related quality of life of preschool children: A systematic review and meta-analysis. PLoS One 2017;12(2): e0172235.

12. Cortes MI, Marcenes W, Sheiham A. Impact of traumatic injuries to the permanent teeth on the oral health-related quality of life in 12-14-year-old children. Com Dent Oral Epidemiol 2002;30(3):193-8.

13. Zaror C, Martinez-Zapata MJ, Abarca J, Diaz J, Pardo Y, Pont A, Ferrer M. Impact of traumatic dental injuries on quality of life in preschoolers and schoolchildren: A systematic review and meta-analysis. Community Dent Oral Epidemiol 2018;46(1):88-101.

14. Jorge KO, Ramos-Jorge ML, de Toledo FF, Alves LC, Paiva SM, Zarzar PM. Knowledge of teachers and students in physical education's faculties regarding firstaid measurement for tooth avulsion and replanatation. Dent traumatol 2009;25:494-9.

15. Panzarini SR, Pedrini D, Brandini DA, Poi WR, Santos MF, Correa JP, Silva FF. Physical education undergraduates and dental trauma knowledge. Dent Traumatol 2005;21:324-8.

16. Vidovic D, Gorseta K, Bursac D, Glavina D, Skrinjaric T. Taekwondo coaches knowledge about prevention and management of dental trauma. Coll Antropol 2014;38(2):681-4.

17. Kumamoto D, Maeda Y. Global trends and epidemiology of sports injuries. J Pediatr Dent Care 2005;11(2):15-25.

18. Andreasen JO, Ravn JJ. Epidemiology of traumatic dental injuries to primary and permanent teeth in a Danish population sample. Int J Oral Surg 1972;1:235-9.

19. Kumamoto D, Maeda Y. A literature review of sportsrelated orofacial trauma. Gen Dent 2004;52(3):270-80.

20. Chan AW, Wong TK, Cheung GS. Lay knowledge of physical education teachers about the emergency management of dental trauma in Hong Kong. Dent Traumatol 2001;17(2):77-85.

21. Mohandas U, Chandan GD. Knowledge, attitude and practice in emergency management of dental injury among physical education teachers: A survey in Bangalore urban schools. J Indian Soc Pedod Prev Dent 2009;27:242-8.
22. Ranalli DN. Sports dentistry in general practice. Gen Dent 2000;48(2):158-64.

23. Perunski S, Lang B, Pohl Y, Filippi A. Level of information concerning dental injuries and their prevention in Swiss basketball-a survey among players and coaches. Dent Traumatol 2005;21(4):195-200.

24. Persic R, Pohl Y, Filippi A. Dental squash injuries - a survey among players and coaches in Switzerland, Germany and France. Dent Traumatol 2006;22(5):231-6.

25. Al-Asfour A1, Andersson L. The effect of a leaflet given to parents for first aid measures after tooth avulsion. Dent Traumatol 2008;24(5):515-21.

26. Emerich K, Wlodarczyk P, Ziolkowski A. Education of Sport University students regarding first-aid procedures after dental trauma. Eur J Paediatr Dent 2013;14(1):3741.

27. Frujeri Mde L, Costa ED Jr. Effect of a single dental health education on the management of permanent avulsed teeth by different groups of professionals. Dent Traumatol 2009;25(3):262-71.

28. Ghadimi S, Seraj B, Keshavarz H, Shamshiri AR, Abiri $R$. The effect of using an educational poster on elementary school health teachers' knowledge of emergency management of traumatic dental injuries. $J$ Dent 2014;11(6):620-8

29. Cecilia Young, Kin Yau Wong, Lim K. Cheung. Effectiveness of educational poster on knowledge of emergency management of dental trauma - Part 2: cluster randomised controlled trial for secondary school students. PLoS One 2014;9(8): e101972

30. Lieger O, Graf C, El-Maaytah M, Von Arx T. Impact of educational posters on the lay knowledge of school teachers regarding emergency management of dental injuries. Dent Traumatol 2009;25(4):406-12. 